\title{
Determinant Factors of Information Technology Adoption in Creative Business and The Result of Its Application: Case of SMEs Cluster in South Bandung
}

\author{
Wawan Dhewanto, Yuliani Dwi Lestari, Sri Heliana*, Qonita Himmatul Aliya, Nur Lawiyah \\ Institut Teknologi Bandung, School of Business and Management, Bandung, Indonesia
}

\begin{abstract}
The expansion of information technology and electronic commerce in Indonesia has provides the opportunities for entrepreneurs to develop their business. It can be seen from the rapid growth of SMEs and creative business in Indonesia increased from year to year. Most SMEs have adopted information technology and electronic commerce (e-commerce) for their business. E-commerce was really famous in today business to be discussed. In general ecommerce is radically changing traditional ways of doing business. The government says ecommerce has huge potential to build the economy of the nation because the large number of internet users increase continuously and become the first factors of adopting technology of ecommerce by the organization. Various research has been analyzed widely the adoption of ecommerce by SMEs. The purpose of this research is to examine determinant factors of adoption of technology ecommerce in SMEs and the impact on their organizational business as a result of level of success. Firstly, empirically investigate the determinants factors in internal and external by conducting interview. Secondly, provide new direction addressing why the business adopt ecommerce and what are concerning factors in adopting ecommerce with a successful. Analysis was done by comparing and analyzing six SMEs in South Bandung in a cluster that have same of types of products and adopt technology ecommerce but have a different in many ways. As the result of this study, limited human resource capacity and skills is the main constrains faced by SMEs when adopting technology ecommerce.
\end{abstract}

\section{Introduction}

The growth of SMEs in Indonesia has rapidly increased from year to year. General Secretary of the ministry of cooperatives and SMEs, Agus Muharram said, about 8 million more new SMEs growing in the year of 2016, 10 million more being targeted at the end of 2018 and its predict to continue growing by $5 \%$ of population in Indonesia or about 13 million more new SMEs at the end of 2019. It is aligning with the rapid advances in technology that changed the trading system from originally offline being online and create the fastgrowing SMEs in this last five years [1]. The expansion of information technology and electronic commerce in Indonesia has provides the opportunities for entrepreneur to develop their business. Most SMEs have adopted information technology and electronic commerce (e-commerce) for their business. Although it has not reached $50 \%$ of the total number of SMES, but its growth steadily and significantly increases. Data from the Directorate General of small and medium Industry in 2015, around 40 percent from the number of SMEs who already utilizing the sophistication of information technology to develop its business. However, the sales of ecommerce in Indonesia are extremely high, in 2017 around 98.5 trillion rupiah obtained from the sales in ecommerce [2].

E-commerce was really famous in today business to be discussed. In general e-commerce is radically changing traditional ways of doing business. The government says ecommerce has huge potential to build the economy of the nation. The magnitude of the potential of ecommerce is not separated from the development of the internet users in Indonesia. Large number of internet users in Indonesia increase continuously and become the first factors of adopting technology of ecommerce by the organization. According to kompas.com [3], more than 50 percent or around 143 million people have connected the internet network throughout the 2017. Much increased from the previous two years that reached 93.4 million people. Report from the Association of Internet service provider in Indonesia (2015), the majority of internet users as much as 72.41 percent is urban people. The utilization of internet itself already much further, not only to communicate but also to purchase goods, order a transport, to do business and work. From the total number of internet users in Indonesia, the potential of ecommerce seen in $77 \%$ of internet users that used internet for searching information about product and shop online [4].

\footnotetext{
* Corresponding author: sri.herliana@sbm-itb.ac.id
} 
As a comparison of the benefits of using ecommerce for business growth, SMEs that use the internet or ecommerce can grow $10 \%$ over than haven't used it [5]. Given the significance of the utilization of ecommerce in business development of SMEs and in line with the vision of the Ministry of industry to encourage the SMEs in utilize information technology to compete on the global market, an in-depth study need to be done by doing research about the adoption of e-commerce by SMEs and what determinant factors that affected the success of the SMEs. The purpose of this research is to examine determinant factors of adoption of technology ecommerce in SMEs and the impact on their organizational business as a result of level of success. Firstly, empirically investigate the determinants factors in internal and external by conducting interview. Secondly, provide new direction addressing why the business adopt ecommerce and what are concerning factors in adopting ecommerce that brought on the maximal results.

\section{Literature Review}

Information technology has the potential of helping SME in supporting market research and global marketing. The growth of information technology has helping business owner in tackle their problem with issues such as cost control and accounting, competition, merchandising, and the need for more skilled personnel [6]. Arthur Andersen (1995) found that having computers, upgrade systems, access internet and use an online service were more likely than average of companies that fast growing. Recent media have been a great deal on how small business are using information technology to compete with the huge companies within their industries. Massey (1987) urged small business owners in order to exploit their networking potential they should considering the revenue of generating potential of computers. Customer service, ordering, sales analysis, correspondence, and distributor support are include as suggested application in information technology. Small businesses encounter special problems when implementing information systems, among them lack of experience, cost overruns, and inadequate expert support $[7,8]$. They run the risk of never "catching up" with larger firms and being bought out by more efficient larger enterprises [9]. There is also concern over the ability of SMEs to benefit from these networks. The empirical evidence suggests that small and medium enterprises are ill-equipped to benefit from these new technologies.

\subsection{E-commerce and Small Medium Enterprise}

Electronic Commerce (e-commerce) is a concept that is commonly described as the process of buying and selling goods or services on the World Wide Web of the Internet [10] or the process of selling or exchanging products, services and information through the network information including the internet [11]. Laudon and
Traver, in Ahmad et al. (2014) defined e-commerce as a set of transaction processing products, services and information exchange using the internet or intranet computer network [12]. Huniati et al. (2009), describe the benefits of ecommerce in particular SME business activities include: providing broader opportunity for perpetrators of SMES to enter the national market and the global market where not previously affordable, increase the intensity of the communication between business, increase the acquisition of access to information, improve and expand marketing and transactions between consumers and suppliers [13]. Purbo and Wahyudi (2001) says companies that use Ecommerce will get a number of benefits, namely [14]: (a) Opening the new revenue stream that is more promising that cannot be found in traditional transaction systems; (b) Increase market exposure; (c) Lower operational costs; (d) Expand the reach, increase customer loyalty, improve supplier management; (e) shorten production time and increase the value chain. The important things in the process of e-commerce business is to build relationships with consumers by providing confidence and guarantee security in the transaction. Brand building activities are key in obtaining a sustainable competitive advantage [15]. According to Anderson and Srinivasan (2003), trust and perceived value is an important determinant in satisfaction on loyalty [16]. Based on the type, ecommerce is divided into 4 categories for this research that are, social media, website, email, and marketplace. Social media in ecommerce is media that frequently used by people to communicate with other then utilized by the business to attract people, it is included Instagram, Facebook, Line@, BBM, Twitter, and Youtube. Some research categories website as social media but on this research, website is separate categories because people doesn't frequently used website to communicate and compare with other social media, in using and creating account of website need more challenging than social media that free account. Marketplace is the media create as an intermediary in business transaction, the seller will not get the payment directly from the buyer but will get the payment from the market place as intermediary after the transaction success with the buyer. Marketplace are included Lazada, Tokopedia, Bukalapak, Shopee, Blibli, Elevenia, Matahari Mall, Zalora, Bhineka, JD.ID and many more [2].

\subsection{Factors Influencing IT (e-commerce) adoption in SME}

Some researchers have posited the factors that influence the adoption of ecommerce. Olatokun and Kebonye (2010) said, factors influencing SMEs to adopt information technology affected by the pressure of external factors i.e. competitors, consumers, business partners, media and the public [17]. Those factors influence directly or indirectly in the adoption of information technology. Size also affects the adoption of information technology, where the smaller 
size of business will be the smaller desire to advantage the information technology. This is because of the limitations or resource scarcity, financial constraints, the ability to compete are low, and human resource constraints. According to Hussin and Noor (2005) explained that the factors influence in adoption of ecommerce on SMES in developing countries include [18]: (a) Relative benefits will received by SME adoption of e-commerce such as: cost efficiency, outreach to a wider market (b). Compatibility, that shows how to implement new technology innovations in accordance with the existing business process on SMEs, (c). Complexity that indicates the level of complexity or difficulty faced by SMES by adopting ecommerce, (d) Trialability or the ability to be tested, ecommerce can be tested if it is able to bring a shift or change in business and the existence of support funding to cover the costs to start testing, (e) Observability or can be observed, that shows the ability to see the results of the benefits from the implementation of e-commerce. Other researcher said [19], Factors that affect SMEs in adopting e-commerce in developing countries are follows a) Organizational Factors including: awareness, Business Resources, Owner's Support, Human resources, I.T. Expertise, and Technology Resources. b). External Factors including: Market forces, Government, Supporting industries, and Competitive pressure. c) Innovation Factors including: Relative advantage, Compatibility, Cost, and image. Based on the research above in general, organization, technology and environment are the factors that influenced SMEs in adopting information technology or e-commerce.

The adoption of information technology, on this research is ecommerce, by SMEs can divided into 2 part these are internal and external factors that exist in SMEs. From the studies have been done, all the determinant factors include in three major aspects that are organization, technology and environment [20]. Organization, which is in the internal factor, environment is an external factor, while technology can be internal and external factors that affects SMEs in the adoption of ecommerce. Based on study above, internal factors include; awareness, business resource, owner support, human resource, IT expertise, technology resource, size of business (financial), and innovation factors (compatibility, cost, and image). While external factors included; competitors, competitive pressure, customers, business partner, market forces, government policy, supporting industries, and market trend.

\section{Methodology}

The method used on this research is descriptive analysis that support for this research to gain deep understanding of the findings and research conduct to create SWOT analysis. Qualitative method also conducts by observing and interviewing the respondents. One of the purposes of this research are to provide direction addressing what are concerning factors in adopting ecommerce to be success.
Comparing and analyzing a few SMEs that used ecommerce is a solution. Then the respondents of this research are six SMEs that have same of types of product and adopt technology ecommerce but have a different in many ways. This research was taking the SMEs in south Bandung in the field of fashion textile as an object.

\section{Finding Arguments}

One of the uniqueness of SMEs compared to large scale business unit is located on the management style. In general, most SMEs rely heavily on intuition the owners, the decision-making process on SME is done centrally [21]. These conditions make the individual context becomes one of special consideration in the adoption of e-commerce [22]. Many people have accepted the innovation as the important of individual's competence. The success of the adoption of ecommerce for SMEs depends on the level of mastery of information technology from the owner, as initiator and determinant business decisions [22,23].

\subsection{SWOT analysis of Factor influencing}

Based on interview, these are internal and external factors influenced SMEs in adopting ecommerce. Those factors have positive impact but also can bring negative impact for the SMEs in adopting technology. The SME should aware with the possibility that might happen when they are adopting ecommerce. From the internal and external factors, creating SWOT analysis to be more clearly understanding the factors that can be strength, weakness, opportunities, and threat faced by the SMEs when adopting ecommerce.

Table 1. SWOT Analysis of Information Technology

\begin{tabular}{|c|c|c|}
\hline $\begin{array}{l}\text { I } \\
\text { N } \\
\text { T } \\
\text { E } \\
\text { R } \\
\text { N } \\
\text { A } \\
\text { L }\end{array}$ & $\begin{array}{l}\text { STRENGTHS } \\
\text { - Awareness of technology } \\
\text { - Owner support to adopt ecommerce } \\
\text { - Do not require a lot of cost in operational } \\
\text { - Size of business (Small and micro business } \\
\text { can run ecommerce) } \\
\text { - Fast branding by using ecommerce } \\
\text { - Distribution of shipping worldwide }\end{array}$ & \begin{tabular}{l}
\multicolumn{1}{c}{ WEAKNESSES } \\
- Less technology knowledge \\
- Less IT expertise \\
- Unstable management (most of the SMEs) \\
- The complexity on using technology
\end{tabular} \\
\hline $\begin{array}{l}E \\
X \\
T \\
E \\
R \\
N \\
A \\
L\end{array}$ & \begin{tabular}{ll} 
& \multicolumn{1}{c}{ OPPORTNITIES } \\
- & Market trend in using IT \\
- & Government policy that support the \\
- & development of IT (ecommerce) by SMES \\
- & Market forces in tod in using internet \\
- & Supporting industries such as logistic \\
company
\end{tabular} & \begin{tabular}{l}
\multicolumn{1}{c}{ THREATS } \\
- Large number of competitors \\
- Competitive pressure (in pricing, quality, \\
branding, etc.) \\
- No barrier entry
\end{tabular} \\
\hline
\end{tabular}

On the Table 1, internal factors creating strength and weakness for adopting ecommerce, while external factors create the opportunity also threat for SMEs in adopting ecommerce. But the strength and opportunities on Table 1 above can be the positive impact and beneficial to adopt technology by SMEs. The weakness of this factors can be obstacles from adopting technology that are less technology knowledge, limited skill in IT, complexity in exploiting 
IT. All the obstacles factors are come from the human resource ability. But human is the fast learning, the weakness can be the strength when the human skill ability in IT are growing. Research conducted by Yulimar and Setiawan (2008) explains that the compatibility, support management, organizational readiness, external factors, and the perceived benefits have influence positively and significantly to the adoption of e-commerce. Those results also show the adoption of e-commerce have positive and significant influence on the company performance [24].

\subsection{Concerning factors in adopting ecommerce}

In the previous explanation, SWOT analysis was creating to determine the factors in adopting ecommerce by SMEs. What is the strength and weakness in adopting ecommerce also the opportunity and the threat that should be concerned in build the business. The next step after knowing the factors affected SMEs in adopting ecommerce, is how to apply this ecommerce correctly to obtain maximal in results. As the goal in business is to get the highest possible income. As it is known, the adoption of ecommerce has many benefits, but not all SMEs can get the maximal benefit from ecommerce. It can be seen from the achievement of SME after using ecommerce. Because, not a few of SMEs that failed in operating the ecommerce. The existence of other factors that should be concerned by SMEs after adopting ecommerce technology to be successful in the application.

This research was interviewing the respondent to analyze the concerning factors to be success in applying ecommerce. There are 6 respondents who participated in this study, all of which are engaged in the same field and have the similar product that is curtain. Even they sell similar product with only differentiate in several motif design, they have many similarities but also the differences. The companies named by $L G, A G, I C, Z N, U G$, and GO. LG Company started their operational in 2014, ZN and GO Companies started their operational a year after LG Company in 2015, while other companies that are AG, IC, and UG started their company in 2016. All of the companies are selling curtain and the accessories of curtain itself. From the six companies, only three companies owned an offline store that are LG, IC, and GO Companies. Other three companies only use online sales, because create the offline store takes a lot of cost. But ZN company thinks to have an offline store after collecting the fees, because ZN's owner says have an offline store can increase the credibility and the existence of their business. Five of the six companies have a tagline as their marketing media, only GO company do not have a tagline. Further description can find in the Table 2. Based on the results of study in the Table 2 above, the average of companies started their business in 2015-2016, all of the companies still classified as Startup Company for duration less than 5 years. Those company are located in the same area in
South Bandung. They even got the supply of their raw materials from the same distributor. But it can be seen that their market reach is around the nation. All of the companies make the transaction via online or internet, but several company that are LG, IC, and GO provided offline store that can be directly visited by the customers. The six companies selling the similar product with good quality, with the number of varieties that are not significant. The company also has multiple accounts in their media ecommerce with competitive price. The critical differences from this six companies are in the revenue they obtained that become the level of their successful in adopting ecommerce.

Number of percentages of revenue on Table 2 obtained from the company's revenue split with the total revenue of all company. As the result in percentage of revenue on Table 2, shows that LG Company has superior in the revenue compared with other company, while other companies have a percentage that is not much different. This research will analyze the highest and the lowest revenue of the respondents. The lowest revenue obtained by GO Company which founded a year after LG Company. From the six companies, LG Company stand longer and the first in this business on that area based on the interview. AG Company although still under the LG on the revenue only a half of LG Company, but they are growing rapidly outperformed than other companies in fact ZN and GO company that stands before AG's company. The Table 2 also shows the number of accounts of ecommerce owned by the companies. All of companies have more than three accounts in ecommerce media. But LG Company have most multiple accounts followed by AG and IC Company. Only LG and ZN Company who owned their website, as for the others, almost all companies use the same in media e-commerce that are social media, email and marketplace. Based on the interview, all of companies stated their largest in revenue gained from the use of media marketplace. It is the reason why all of the companies joined many marketplaces with multiple accounts. Because they believe having many accounts will enlarge their opportunities to be seen by customers.

Based on the interview result, that are factors influenced the six companies on their successful. The most consideration on the successful in adopting ecommerce that are management of the company itself especially in term of management of its information technology. The concerning factors in adopting ecommerce are summarized below:

1. IT management. It is included human resource and skill capacity in using technology. The owner of LG Company has knowledge and skill in IT more than the other owner. As state before most SMEs are relied heavily on intuition the owners, make the decision-making process is done centrally. It was concluded that the commitment of the business owners was very influential in the success of the process of adoption. Business owners in this matter assessed to have a significant influence and authority against other individuals to accept the changes. Secondly the employee that engaged in the 
company also have a big role in adopting technology successfully. Human resource is really important, on this field human resource required is that have skill in using IT. The company need resource of human that want to be learning to develop themselves following the changes of time, the changes of technology.

2. Price. Price become very important by SMEs who adopted ecommerce. Because with using ecommerce, customers can easily compare the price with other competitors. As customer behavior to get the lowest price with the best quality. This is what AG's company implement. They are placing the lowest price than other companies to attract more customers. Somehow lowering the price even only Rp.100, cheaper than other company can be affected. This is call as pricing strategy.

3. Number of accounts of media ecommerce. In term of ecommerce, multiple accounts same as the number of stores or branch owned. The more number of accounts, the more possibility of transaction that will happen. Have multiple accounts also make the product easy to be found by customers. Internet search engine will randomly display the product, the more accounts or online shop the more possibility the product will be display when customer click the keyword. Have many accounts should be coupled with a number of human resources that are able to operate it. On this case ZN Company doesn't have enough resource to operate their ecommerce, and it became one of the reasons ZN's revenue are below AG's and IC's revenue although $\mathrm{ZN}$ establish ahead of them but $\mathrm{ZN}$ cannot compete with them because of less human resource.

4. Quality of product. Quality of product in ecommerce cannot be ascertained and measured clearly because the customers do not see the product directly in person. The product can only be seen digitally by the photo or video with additional description regarding the product. It makes the photo of the product is very important as a representation of the quality of products as well as the image of the company. The company must be able to display photos of the products as good and interesting as possible without eliminating the authenticity of the original image of the product.

Those are the factors influence the six companies on their successful. It can be the concerning factors for other SMEs when deciding to adopt ecommerce technology to operate ecommerce appropriately.

\section{Conclusions}

The adoption of information technology by SMEs divided into internal and external factors. Those factors influenced the SMEs in adopting ecommerce, it can give positive impacts but also negative impacts. Then using SWOT analysis to be grouping the factors to find the strength, weakness, opportunity, and threat which can help the SMEs in adopting ecommerce. All the determinant factors include in three major aspects that are organization, technology and environment. Limited of human resource in skill ability of using technology become the weakness also the obstacle in adopting ecommerce, but that can be covered by learning and training. This research proves other studies who stated organization, technology, and environment are the determinants factors influenced in adopting technology. From the three factors, based on the result on this study, organization factor is the most influencing factor to adopting ecommerce successfully. Because the organization who operate the business and will operate the adopting of ecommerce. Operate ecommerce appropriately will bring to expected result. There are four factors in the organization that should be concerned by SMEs in order to get the maximum result in adopting technology ecommerce; a) IT management, it is included human resource and skill capacity in using technology, b) Pricing, c) Number of accounts of media ecommerce, d) Quality of product, can be seen as photo product. The four factors can increase the probability to be success in adopting ecommerce.

\section{References}

1. Ministry of Cooperation and Small and Medium Enterprises of the Republic of Indonesia. Data UMKM. Retrieved April 22, 2018 from http://www.depkop.go.id/berita-informasi/datainformasi/data-umkm/

2. katadata.co. (2018). databoks.katadata.co.id. Penjualan e-Commerce Indonesia Mencapai US\$ 16 Miliar: Retrieved 2018 from https://databoks.katadata.co.id/datapublish/2018/0 2/12/2022-penjualan-e-commerce-indonesiamencapai-rp-16-miliar

3. F.K Bohang, tekno.kompas.com. Jumlah Pengguna Internet Indonesia? Retrieved 2018 from

https://tekno.kompas.com/read/2018/02/22/16453 177/berapa-jumlah-pengguna-internet-indonesia

4. A.N. Hanum, A. Sinarasri, Analisis Faktor-Faktor Yang Mempengaruhi Adopsi E Commerce dan Pengaruhnya Terhadap Kinerja Umkm (Studi Kasus Umkm Di Wilayah Kota Semarang). 15. (2017)

5. A. Nuvriasari, Peran Dukungan Organisasional, Kompetensi Teknologi Dan Lingkungan Eksternal Dalam Rangka Mendorong Pengadopsian E-Commerce Pada Usaha Kecil Menengah. Siasat Bisnis, 205-217. (2012)

6. C. Nyandoro, Factors Influencing Information Communication Technology (Ict) Acceptance and Use in Small and Medium Enterprises (Smes) In Kenya. Capella University. (2016)

7. M.J. Smith, M.V. Flinders, Quangos, Accountability and Reform: The Politics of Quasi-Government, (Springer, 2016)

8. X. Granell, Multilingual information Management: Information, Technology \& Translators, (Chandos Publishing, 2014) 
9. J.Y.L. Thong, C.S. Yap,CEO characteristics, organizational characteristics and information technology adoption in small businesses, Omega, Elsevier, Vol. 23(4), pages 429-442, (1995)

10. J. Shim, A. Qureshi, J. Siegel, \& R. Siegel. The International Handbook of Electronic Commerce. (The Glenlake Publishing Company Ltd, Chicago, 2000)

11. E. Turban, D. King, J.L. Lee, M. Warkentin, H.M. Chung, Electronic Commerce 2002: A Managerial Perspective, (Pearson, 2002)

12. S. Z. Ahmad, A.R. Abu Bakar, T.M. Faziharudean, \& K.A.M. Zaki,. An empirical study of factors affecting e-commerce adoption among small and medium sized enterprises in a developing country: Evidence from Malaysia. Information Technology for Development, Vol. 21 No. 4. (2015)

13. Z. Hunaiti, R. Masa'deh, and M. Mansour, Electronic Commerce Adoption Barriers in SMEs in Developing Countries: The Case of Libya, IBIMA Business Review, Vol. 2, 2009

14. O.W. Purbo, A.A. Wahyudi. Mengenal eCommerce, (PT. Elex Media Komputindo, Jakarta, 2001)

15. M. Gommans, K.S. Krishnan, \& K.B. Scheffold, From Brand Loyalty to E-Loyalty: A Conceptual Framework, Journal of Economic and Social Research, 3(1), pp. 43-58, (2001)

16. R.E. Anderson, K. Srinivasan, E-Satisfaction and E-Loyalty: A Contingency Framework, Psychology and Marketing, 20(2), 123-138, (2003)

17. Olatokun, W. et al. e-Commerce Technology Adoption by SMEs in Botswana. International
Journal of Emerging Technologies and Society, 8(1). (2011)

18. Hussin, H. et al. Innovating Business Through ECommerce: Exploring the Willingness of Malaysian SMEs. The second International Conference on Innovation in IT. (2005)

19. K. Salah, B, Irwin. A Structural View of ECommerce in SMEs In Least Developing Countries. $18^{\text {th }}$ European Conference on Information System. (2010)

20. Almoawi, A. et al. Applying the Role Model in Determining the E-Commerce Adoption on SME In Saudi Arabia. Asian Journal of Business and Management Service, 1(7), 12-24. (2010)

21. R.C. Macgregor, M. Kartiwi, Perception of barriers to e-commerce adoption in SMEs in a developed and developing country: a comparison between Australia and Indonesia. Journal of Electronic Commerce in Organizations, 8 (1), 6182. (2010).

22. R. Rahayu, J. Day, Determinant Factors of E Commerce Adoption by SMEs in Developing Country: Evidence from Indonesia. ProcediaSocial and Behavioral Science 195, 142-150. (2015)

23. E. Cloete, S. Courtney, \& J. Fintz. Small businesses acceptance and adoption of ecommerce in the Western Cape Province of South Africa. Electronic Journal on Information Systems in Developing Countries, Vol. 10 No. 4. (2002)

24. V.A. Yulimar, A. Setiawan, Analisis Faktorfaktor yang Mempengaruhi Pengabdosian electronic commerce dan Pengaruhnya Terhadap Kinerja Perusahaan. Journal IST AKPRIND Yogyakarta.

(2008)

Table 2. Respondent description

\begin{tabular}{|c|c|c|c|c|}
\hline Company & Product & Quality and Price & e-commerce & $\begin{array}{l}\text { Percentage of } \\
\text { Revenue }\end{array}$ \\
\hline LG & $\begin{array}{l}\text { It has about } 60 \text { types of } \\
\text { curtains with a different } \\
\text { motif or color. Provide } \\
\text { the most choice of motifs } \\
\text { and colours. }\end{array}$ & $\begin{array}{l}\text { Provide good quality } \\
\text { product with a high price } \\
\text { than other companies. }\end{array}$ & $\begin{array}{l}\text { SosMed: Instagram (3), facebook ads, } \\
\text { BBM, youtube } \\
\text { Website } \\
\text { Email } \\
\text { MP : Tokopedia (5), Bukalapak (2), } \\
\text { Lazada (1), Shopee (6), Blibli (3) }\end{array}$ & $35,7 \%$ \\
\hline $\mathrm{AG}$ & $\begin{array}{l}\text { It has about } 50 \text { types of } \\
\text { curtains with a different } \\
\text { motif or color. }\end{array}$ & $\begin{array}{l}\text { Provide good quality and } \\
\text { medium quality of } \\
\text { product with the lowest } \\
\text { price than other } \\
\text { companies. }\end{array}$ & $\begin{array}{l}\text { SosMed: Instagram, Facebook Ads } \\
\text { Email } \\
\text { MP: Tokopedia (4), Bukalapak (1), } \\
\text { Lazada (1), Shopee (7), Blibli (1) }\end{array}$ & $17.1 \%$ \\
\hline $\mathrm{IC}$ & $\begin{array}{l}\text { It has about } 40 \text { types of } \\
\text { curtains with a different } \\
\text { motif or color. Provide } \\
\text { most complete in } \\
\text { accessories of curtain } \\
\text { than other }\end{array}$ & $\begin{array}{l}\text { Provide good quality } \\
\text { product with a medium } \\
\text { lower price. }\end{array}$ & $\begin{array}{l}\text { SosMed: Instagram (3), facebook ads, } \\
\text { youtube } \\
\text { Email } \\
\text { MP : Tokopedia (5), Bukalapak (2), } \\
\text { Shopee (5), Blibli (2) }\end{array}$ & $14,3 \%$ \\
\hline $\mathrm{ZN}$ & $\begin{array}{l}\text { It has about } 45 \text { types of } \\
\text { curtains with a different } \\
\text { motif or color. }\end{array}$ & $\begin{array}{l}\text { They provide good } \\
\text { quality product with a } \\
\text { medium high price than } \\
\text { other. }\end{array}$ & $\begin{array}{l}\text { SosMed: Instagram (3), facebook ads, } \\
\text { Website } \\
\text { Email } \\
\text { MP : Tokopedia (3), Bukalapak (2), } \\
\text { Lazada (1), Shopee (4), Blibli (1) }\end{array}$ & $12,2 \%$ \\
\hline $\mathrm{UG}$ & It has about 45 types of & Provide & SosMed: Instagram (2), facebook ads & $11,4 \%$ \\
\hline
\end{tabular}




\begin{tabular}{|c|c|c|c|c|}
\hline & $\begin{array}{l}\text { curtains with a different } \\
\text { motif or color. }\end{array}$ & $\begin{array}{l}\text { product with a medium } \\
\text { lower price. }\end{array}$ & $\begin{array}{l}\text { Email } \\
\text { MP : Tokopedia (4), Bukalapak (2), } \\
\text { Lazada (1), Shopee (5), Blibli (1) }\end{array}$ & \\
\hline GO & $\begin{array}{l}\text { It has about } 40 \text { types of } \\
\text { curtains with a different } \\
\text { motif or color. }\end{array}$ & $\begin{array}{l}\text { Provide good quality } \\
\text { product with lower price. }\end{array}$ & $\begin{array}{l}\text { SosMed: Instagram (1), facebook ads } \\
\text { MP : Tokopedia (4), Bukalapak (2), } \\
\text { Lazada (1), Shopee (5), Blibli (1) }\end{array}$ & $9,3 \%$ \\
\hline
\end{tabular}

$(\mathrm{)})$ : number of accounts 